\title{
Ascending placentitis in the mare: A review
}

Cummins, C., Carrington, S., Fitzpatrick, E. and Duggan, V. School of Agriculture, Food Science and Veterinary Medicine University College Dublin Belfield, Dublin 4

Ascending placentitis is a condition that occurs late in pregnancy when bacteria enter the sterile uterus from the lower reproductive tract. It leads to abortion or the birth of premature and weakened foals. Early detection and treatment of this condition is vital for ensuring the production of a viable foal.

Mares with ascending placentitis often present in late term pregnancy with signs of premature udder development and premature lactation. There may be a vulvar discharge. Early detection of placental problems is possible using trans-abdominal or trans-rectal ultrasonography. Hormones such as progesterone and relaxin may be measured as indicators of foetal stress and placental failure. Postpartum foetal membranes may be thickened and contain a fibronecrotic exudate. The region most affected is the cervical star. Definitive diagnosis of ascending placentitis is by histopathological examination of the chorioallantoic membrane.

Ideal treatment strategies are aimed at curing the infection and prolonging the pregnancy to as close to term as possible and consist of anti-microbials, anti-inflammatories and hormonal support.

Swabs are taken from affected mares to determine antibiotic sensitivity and to aid in treatment of foals born from these mares which are at risk of becoming septic. If detected early enough, the chances of producing a viable foal are greatly increased..

Key Words: ascending, placentitis, pregnancy loss, mare

\section{Corresponding author:}

Carolyn Cummins

School of Agriculture, Food Science and Veterinary Medicine

University College Dublin

Belfield, Dublin 4

Email: Carolyn.cummins@ucd.ie

\section{Introduction}

Ireland is the main European producer of Thoroughbred (TB) horses and is responsible for a third of worldwide TB production (Indecon, 2004 ). There were approximately 30,000 Thoroughbred broodmares at stud in 2006 in Ireland and the UK. Of these, 23,400 were mated to Thoroughbred stallions. The conception rate, excluding mares that were exported or died, was $97 \%$. The pregnancy failure rate was $8 \%$ (Ricketts, 2007). These numbers show that although few mares fail to go in foal, a considerable number will lose the foal during the pregnancy.

The failure of pregnancy can be due to foetal or maternal factors and dysfunction of the placenta (Troedsson and Sage, 2001). This review focuses on the loss of late term pregnancy due to infection, specifically ascending placentitis, in the mare.

Ascending placentitis is infection of the placenta by bacteria that migrate along the reproductive tract from the vagina through the cervical canal. This can lead to abortion, premature birth or the birth of a weak foal, and affected mares often have difficulties conceiving during the following breeding season (Troedsson and Zent, 1997; Troedsson and Sage, 2001). The condition is seen in late gestation, typically at eight to 10 months.

The current incidence of ascending placentitis in Ireland is unknown. It accounts for nearly $20 \%$ of all equine abortions, stillbirths and perinatal deaths in the USA (Giles et al., 1993). In the UK it is implicated in $10 \%$ of such cases (Smith et al., 2003). Reasons for this regional difference are unknown.

\section{Normal anatomy and physiology}

The uterus of the normal pregnant mare provides a sterile environment for the developing foetus. The embryonic part of the placenta is made up of two membranes: the amnion, which surrounds the foetus and the outer, thicker diffuse microcotelydonary chorioallantois. The chorioallantoic membrane is covered in villi which interdigitate with crypts on the endometrium. It is attached to the endometrium diffusely, except for an area adjacent to the cervix (England, 1996; McGeady et al., 2006). This area, known as the cervical star, is the area most affected in ascending placentitis (Troedsson and Sage, 2001; McGeady et al., 2006). The placenta functions to allow selective exchange of nutrients, gases and waste products throughout pregnancy (Troedsson and Sage, 2001; Fowden et al., 2004; McGeady et al., 2006). In order for the mare to maintain pregnancy, a healthy placenta is required. Placental dysfunction may occur when there is a decrease in the villous attachment of the chorioallantois to the endometrium (Bucca et al., 2005). An example of this occurs in twinning where there is insufficient space for the development of two placentas and 


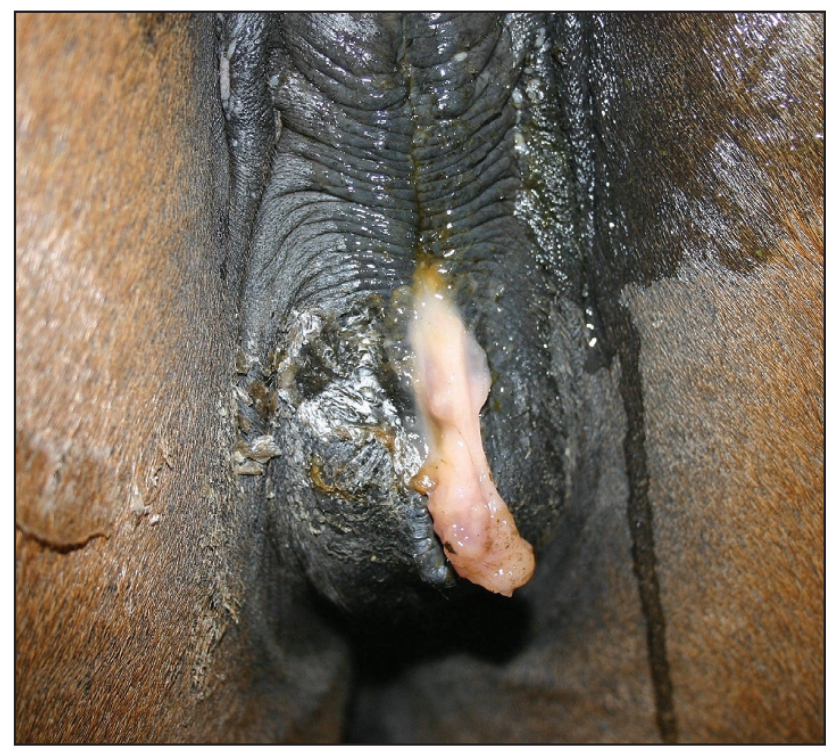

Figure 1: Disintegration of the cervical mucus plug in a peri-parturient mare. Photo: Siobhan McAuliffe.

abortion occurs as a result (McKinnon and Voss, 1993a). The normal cervix and lower reproductive tract act as a physical barrier to the entry of micro-organisms and foreign material to the foetoplacental environment. The cervix has a thick muscular layer which is rich in elastic fibres (McKinnon and Voss, 1993b). During pregnancy the cervix is closed. However, at all stages of pregnancy it is possible to pass a finger through the cervical canal into the uterus (England, 1996). The epithelial secretory cells of the cervix and lower reproductive tract produce mucus. This production is regulated, in part, by circulating hormone (Lagow et al., 1999). The consistency of the mucus varies during the different stages of the cycle (Katz et al., 1997). During dioestrus and pregnancy, under the influence of progesterone, cervical mucus is viscous and impermeable to bacteria and foreign material. In fact, during pregnancy a thick mucus plug forms in the cervical canal and projects into the vagina (Nishikawa, 1959) (Figure 1).

\section{Ascending placentitis and its effect on the foetoplacental unit}

Ascending placentitis occurs when bacteria migrate along the reproductive tract from the vagina through the cervical canal and cause infection in the cervical star region of the chorioallantois, which subsequently spreads centripetally along the placenta (Calderwood et al., 2002; Macpherson, 2005) (Figure 2). The migration of bacteria leads to a necrotising inflammation of the chorioallantois (Calderwood et al., 2002) and upregulates the expression of pro-inflammatory cytokines in the placental tissue (LeBlanc et al., 2002). This leads to the production of prostaglandins by the placenta, which may cause uterine contraction and premature labour (LeBlanc et al., 2002; LeBlanc et al., 2004). Inflammation, thickening and separation of the chorioallantois, if diffuse, may impede the provision of oxygen and nutrients to the foal (Reef et al., 1995; Morresey, 2005). Finally, infection can extend to the foetus resulting in abortion or the birth of a weak or septic foal (Calderwood et al., 2002). Premature foals from mares affected by placentitis have poor survival rates and require intensive neonatal care (Bain, 2004).

The hypothalamic pituitary adrenal (HPA) axis is fundamental for the final development of the foetus in late gestation and has a function in inducing the onset of parturition (Ousey et al., 1999; Ousey, 2004). The HPA axis of the equine foetus matures very late in gestation compared with other species (Ousey et al., 1999; LeBlanc, 2004a). Increasing levels of pro-inflammatory cytokines or prostaglandins in ascending placentitis stimulate maturation of the foetal HPA axis (LeBlanc, 2004a, 2004b; LeBlanc et al., 2004). Foals from affected mares that survive premature birth may be physiologically underdeveloped but their adrenocortical function may be normal or transitional compared with those born prematurely from unaffected mares (Rossdale et al., 1991; Ousey et al., 1999). These foals may survive with minimal care (LeBlanc, 2004b; LeBlanc et al., 2004). This has implications for treatment of disease. If the length of gestation can be prolonged, the prospect of producing a viable foal can be improved (LeBlanc, 2004b).

\section{Pathophysiology}

In experimentally induced placentitis, a portion of the cervical mucus plug must be removed in order to inoculate the uterus with bacteria (McGlothlin et al., 2004; Morris et al., 2006). Therefore, in naturally occurring ascending placentitis there must be a failure of the mucus plug (McGlothlin et al., 2004) That is, either the plug does not form properly or it disintegrates. The reasons for failure of the mucus plug are, as yet, unknown.

Bacterial vaginosis in pregnant women is a condition similar to ascending placentitis in the mare. The vagina becomes chronically colonised by an abnormal microbial flora. These bacteria produce enzymes which are capable of degrading the cervical mucus plug, thus allowing bacteria access to the placenta (Howe et al., 1999). This leads to inflammation of the placenta and premature labour (Hillier et al., 1995). A similar mode of action may apply in mares with ascending placentitis, whereby abnormal bacteria in the tract produce mucus-degrading enzymes. Certain bacterial pathogens occasionally found in the equine reproductive tract, for

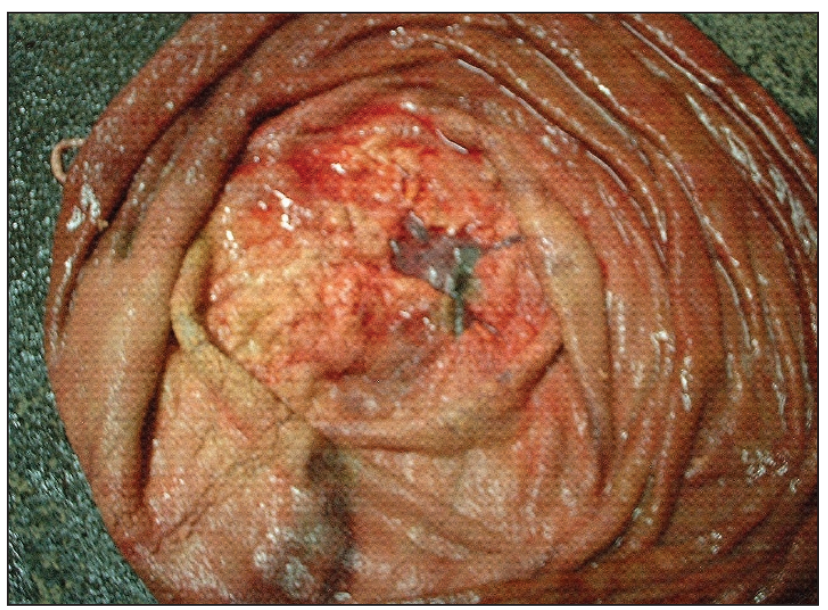

Figure 2: Placenta from a mare with ascending placentitis. The chorioallantoic membrane is thickened and there is a purulent exudate around the cervical star. 
example Pseudomonas aeruginosa, do produce mucus degrading enzymes (Leprat and Michel-Briand, 1980; Soong et al., 2006).

Streptococcus equi subspecies zooepidemicus is the bacteria most often isolated from affected mares. Escherichia coli, Pseudomonas aeruginosa, Klebsiella spp., Leptospira spp., Enterobacter spp., $\alpha$-haemolytic Streptococci, Staphylococci spp. and nocardioforms have also been implicated (Giles $e t$ al., 1993; Hong et al., 1993). It is possible that bacteria may be responsible for the degradation of the mucus plug but are not the pathogens that affect the placenta. These organisms may be facilitatory in degrading the cervical defences, allowing commensals such as $S$. zooepidemicus access to the placenta.

\section{Clinical signs}

Although not a consistent occurrence, premature udder development and lactation in the final trimester of gestation is often the first sign of ascending placentitis (Troedsson and Zent, 1997; Calderwood et al., 2002; LeBlanc, 2004b; LeBlanc et al,. 2004). Rising progestagen concentration in the normal prepartum period is associated with mammary development and lactation (Ousey, 2004). These progestagens may be responsible for prolactin production. Early increases in progestagen levels occur in ascending placentitis. This, in turn, may give rise to the premature lactation, and other clinical signs, seen in this condition (Table 1).

In addition to this, there may be a vulvar discharge (Figure 2) and/or relaxation of the cervix. Alternatively, abortion may occur suddenly in affected animals without any warning signs (Troedsson and Zent, 1997; Calderwood et al., 2002).

Live foals born to mares affected with ascending

Table 1: Clinical signs of ascending placentitis in the mare Clinical signs of ascending placentitis

Premature udder development

Premature lactation

Vulvar discharge

Softening of the cervix

Abortion

placentitis may be premature, weak and/or unthrifty and may develop sepsis (Bain, 2004). Alternately, they may present as a 'dummy' foal, as a result of chronic in utero transplacental oxygen deprivation (Vaala, 1999; Bain, 2004). High creatinine concentrations in the neonatal foal that resolve rapidly over the first day or two suggest placental insufficiency, as the placenta functions as the excretory organ of the foetal foal (Vaala, 1999; Bain, 2004; Morresey, 2005).

\section{Diagnosis}

Early diagnosis of ascending placentitis is essential to increasing the likelihood of producing a viable foal. This condition should be considered as a possible cause in a mare with premature lactation.
Mares that have a vulvar discharge should be carefully examined using a sterile speculum. If the speculum passes easily into the vagina, the cervix can be evaluated for competency, presence of the mucus plug and/or discharge. Care should be taken not to stimulate the cervix during the examination as this can induce premature parturition (Handler et al., 2003). If the speculum does not pass easily, it is likely that the normal thick vaginal mucus is still in place and this should not be disturbed.

Ultrasonography can be used to detect or confirm cases of ascending placentitis in suspect cases showing the classical clinical signs and also in subclinical mares (Reimer, 1997; Kelleman et al., 2002; Bucca et al., 2005; Morris et al., 2006; Troedsson and Macpherson, 2006). Ultrasound scanning can be performed trans-rectally or trans-abdominally. Measurements of the uterine wall and attached chorioallantois may be used to identify mares at risk of ascending placentitis. This measurement is known as the combined thickness of the uterus and placenta (CTUP). If the CTUP is increased, placental insufficiency is likely present and abortion may ensue (Renaudin, et al., 1997; Troedsson and Zent, 1997; Troedsson and Sage, 2001; Kelleman et al., 2002). Measurement of the CTUP can be taken at the placento-cervical junction when scanning trans-rectally or at the uterine body or uterine horns when scanned trans-abdominally (Renaudin et al., 1997).

If scanning trans-abdominally it is suggested to inspect the four quadrants of the placenta: right cranial, right caudal, left cranial and left caudal (Reef et al., 1995; Troedsson and Sage, 2001; Troedsson and Macpherson, 2006). The CTUP should not exceed $8 \mathrm{~mm}$ between days 271 and 300 of gestation, $10 \mathrm{~mm}$ between days 301 and 330 of gestation and $12 \mathrm{~mm}$ after day 330 of gestation (Renaudin et al., 1999) (Table 2). However, placental thickness measurements may vary depending on the area being assessed (Bucca et al., 2005). Measurements of CTUP using trans-rectal ultrasonography are more reliable than trans-abdominal ultrasonography (Renaudin et al., 1997).

Another disadvantage of trans-abdominal scanning is that focal areas of abnormal placenta may be missed as the only parts of the uterus and placenta that can be evaluated are those which are closest to the abdominal wall (Bucca, et al., 2005; Troedsson and Macpherson, 2006). The cervical pole of the placenta, which is the region most affected in ascending placentitis, can be easily evaluated trans-rectally. Examination may reveal separation of the chorioallantois from the endometrium and the presence of pus (Troedsson and Zent, 1997; LeBlanc et al., 2004; Troedsson and Macpherson, 2006). This may lead to identification of ascending placentitis in mares not yet showing clinical signs (Troedsson and Macpherson, 2006). Rectal ultrasound is a routine procedure used to diagnose problems in late term pregnancy. In a study by Renaudin et al. (1997) there were no reports of adverse effects of using rectal ultrasound in late term mares.

The indicators of placental failure in late gestation of the mare observed during scanning are described in Table 3. The foetal heart rate can be evaluated by trans-abdominal 
Table 2: Upper limits for the combined thickness of the uterus and placenta (CTUP) by transrectal ultrasonography during late gestation (adapted from Renaudin et al, 1997)

\begin{tabular}{|l|l|}
\hline Day of gestation & $\begin{array}{l}\text { Normal CTUP } \\
(\mathrm{mm})\end{array}$ \\
\hline $151-270$ & $<7$ \\
\hline $271-300$ & $<8$ \\
\hline $301-330$ & $<10$ \\
\hline $331+$ & $<12$ \\
\hline
\end{tabular}

ultrasound (Table 4). This can give an estimate of foal viability (Reef et al., 1995). Evaluation of the heart rate in response to foetal movement may provide a better measurement of foetal distress than variations in inactive or post-exercise heart rate (Reef et al. 1995). In the compromised foal, the heart rate initially decreases but as the foetus becomes more and more affected, the heart rate increases and severe tachycardia may be appreciated immediately prior to the death of the foetus (Troedsson and Macpherson, 2006).

Plasma levels of circulating hormones may be indicators of foetal stress (LeBlanc et al., 2004). In the normal mare, plasma progesterone concentrations drop to between 3-6ng/ml from day 110 until the tenth month of pregnancy (Terblanche and Maree, 1981) (Table 5). Plasma progestagen levels increase in the last 15-21 days before parturition. These levels fall in the last 48 hours before foaling (Small, 2000; LeBlanc et al., 2004). Prematurely increasing plasma progestagen levels may be an indicator of chronic placentitis or foetal stress (Rossdale et al., 1991; Stawicki et al., 2002; LeBlanc, 2004b; Ousey et al., 2005; Morris et al., 2006). Repeated samples must be taken to confirm diagnosis (Troedsson and Sage, 2001). Increases in progestagens may also indicate increased foetal maturation due to stimulation of the HPA axis by inflammatory cytokines and prostaglandins (LeBlanc, 2004b). In the case of acute placentitis, progestagen levels may drop suddenly. Mares with low levels of serum progestagens and placental infection usually abort spontaneously (Stawicki et al., 2002; LeBlanc, 2004b). Such mares may not be identified even by transrectal ultrasound, as thickening of the placenta or separation may not have occurred (Morris et al., 2006). At this time there is no reliable assay for progestagens available in Ireland.

Relaxin concentrations could potentially be useful in diagnosing insufficiency of the placenta. Relaxin is primarily produced by the placenta (Ousey, 2004). Subnormal levels of relaxin may be present in mares with compromised pregnancies (Ryan et al., 1998; Stewart et al., 1982, cited by Troedsson and Sage, 2001). However, measurement of relaxin concentration is not routinely available at most equine diagnostic centres.

Postpartum examination of the placenta in these cases may reveal thickening and discolouration of the chorioallantoic surface primarily in the region of the cervical star (Morresey, 2005). There may also be a purulent exudate (Troedsson and Zent, 1997; Morresey, 2004; Schlafer, 2004). The cervical star is the area of the chorioallantoic membrane that ruptures during normal delivery. If there
Table 3: Indicators of placental failure, detectable by ultrasound, in late gestation of the mare (adapted from Reimer, 1997 and Troedsson and Macpheron, 2006)

\section{Anomalies detectable by ultrasound}

Noticeable abnormality of foetus, foetal position or foetal activity

Increases or decreases in foetal heart rate

Accumulation of fluid between chorioallantoic membrane and endometrium - leads to placental separation

\section{Thickened placenta}

Abnormalities of the umbilical cord

Greatly increased or reduced allantoic or amniotic fluids Increased echogenicity of the allantoic and amniotic fluids

has been premature detachment of the chorioallantois from the endometrium the rupture may occur in another area (Morresey, 2004, 2005; Schlafer, 2004) and may result in a 'red bag' delivery. The chorioallantoic membrane may appear normal on gross examination; however, microscopically, it may be severely inflamed. Therefore, the foetal membranes including the umbilical cord should be submitted for histopathological investigation to confirm the diagnosis (Calderwood et al., 2002).

In cases of abortion, the foetus and the foetal membranes should be submitted. Uterine swabs should be taken from all mares that deliver prematurely to eliminate bacterial infection as the cause and, if infection is found, to aid treatment of the foal with appropriate antibiotics (Calderwood et al., 2002).

\section{Treatment}

Management of ascending placentitis is aimed at fighting the infection, reducing the inflammatory response and supporting the pregnancy (LeBlanc, 2004d; Macpherson, 2005; Troedsson and Macpherson, 2006). There is a correlation between chronic placentitis and accelerated foetal maturation (Rossdale et al., 1991; LeBlanc, 2004b; LeBlanc et al., 2004). If the pregnancy can be prolonged for a few weeks after the clinical signs of ascending placentitis are first seen, then a premature foal may be born with an improved likelihood of survival (LeBlanc et al., 2004). In other words, the dam is a better incubator for a compromised foal than a neonatal intensive care unit. Broad spectrum antibiotics are used to treat the infection in ascending placentitis (LeBlanc et al., 2004). Potentiated sulphonamides (trimethoprim sulfamethoxazole, $30 \mathrm{mg} / \mathrm{kg}$, BID PO) and penicillin (procaine penicillin 22,000 IU/kg BID IM or crystalline penicillin 22,000 IU/kg QID IV) have been shown to cross the placenta and so are useful where organisms are susceptible to these drugs (Murchie et al., 2003; Macpherson, 2005; Troedsson and Macpherson, 2006). Gentamicin $(6.6 \mathrm{mg} / \mathrm{kg}$ SID IV) has not been shown to achieve a high enough concentration in the allantoic fluid to inhibit Streptococcus equi (Santschi and Papich, 2000). However, it may achieve concentrations adequate to be effective against E. coli and Klebsiella spp. (Murchie et al., 2003; Macpherson, 2005). A swab of the vulvar discharge should be taken to identify organisms and determine antibiotic sensitivity. 
Table 4: Foetal heart rate during pregnancy (adapted from Curran and Ginther, 1995) Month of gestation Heart rate - beats per minute 1 $123-133$ 172-196 6 $126-130$

Inflammation and the increased level of prostaglandins are initiating factors in preterm parturition (LeBlanc et al., 2002). Anti-inflammatories which block inflammatory cytokines may be useful in treating this (LeBlanc, 2004d). It has not yet been determined if flunixin meglumine (1.1 $\mathrm{mg} / \mathrm{kg}$ IV or IM) can transfer across the equine placenta to reach adequate concentrations (Murchie et al., 2003). Mares affected with ascending placentitis may be treated with pentoxifylline $(8.5 \mathrm{mg} / \mathrm{kg}$, BID PO), a member of the methylxanthine class of drugs. Pentoxifylline inhibits the transcription of the tumour necrosis factor-a (TNF) gene and suppresses the production of this proinflammatory cytokine. (Doherty, 1991; Staudinger et al., 1996; Leblanc, 2004a, 2004d; Macpherson, 2005). It is also a rheologic agent which is thought to improve microcirculatory blood flow (Geor et al., 1992).

Tocolytics are given to women in premature labour. These drugs can interrupt the premature uterine contractions and therefore delay impending parturition (LeBlanc et al., 2004). Efficacy in extending gestation has not been proven when these drugs are used alone (Macpherson, 2005; Troedsson and Macpherson, 2006). Clenbuterol has been demonstrated to cause uterine relaxation during late gestation, for up to two hours (Palmer et al., 2002). However, studies have shown that it may cause relaxation of the cervix and treated mares may, in fact, give birth earlier than untreated mares (Card and Wood, 1995; Palmer et al., 2002; Macpherson, 2005; Troedsson and Macpherson, 2006). Therefore, it cannot be recommended that mares suffering from ascending placentitis be treated with clenbuterol.

The synthetic progesterone analogue, altrenogest, is thought to have an anti-prostaglandin effect (Daels et al., 1996; LeBlanc et al., 2004). This can help to maintain the quiescence of the uterus (LeBlanc, 2004c; LeBlanc et al., 2004; Macpherson, 2005). Although the mechanisms are not fully understood, it is often given to mares showing clinical signs of placentitis. Trials on the efficacy of this approach have not yet been undertaken. However, some veterinary practitioners recommend double the normal dose, $(0.088$ mg/kg, SID PO) (LeBlanc, 2004c; Ousey, 2004). Treatment is maintained throughout the remainder of the pregnancy.

\section{Conclusion}

Ascending placentitis is an important cause of late term foetal loss in the mare. Affected mares exhibit premature lactation and may have a vulvar discharge. Early detection of the ascending placentitis and implementation of treatment is critical in increasing the possibility of survival of the neonate.

Diagnosis may be assisted by prepartum ultrasonographic
Table 5: Plasma progesterone levels during pregnancy of the normal mare (adapted from Terblanche and Maree, 1981)

\begin{tabular}{|l|l|}
\hline Day of gestation & $\begin{array}{l}\text { Plasma progesterone level } \\
\text { (ng per } \mathrm{ml} \text { ) }\end{array}$ \\
\hline $21-30$ & $5-9$ \\
\hline $30-60$ & $4-10$ \\
\hline $60-110$ & $7-10$ \\
\hline $110-300$ & $3-6$ \\
\hline
\end{tabular}

evaluation of the foetoplacental unit and treatment is aimed at prolonging the pregnancy to produce a viable foal. Combined therapy of long-term antibiotics, antiinflammatories and synthetic progestagens is used to increase possibility of producing live, viable foals. In addition to the obvious economic consequences of the loss of a viable foal, there is also a decrease in the fertility of the mare for the following breeding season (Troedsson and Zent, 1997; Troedsson and Sage, 2001).

There are still many unanswered questions regarding the pathogenesis of ascending placentitis and the most appropriate treatment strategies. Current research is aimed at determining the predisposing factors, discovering a method of early detection and validating appropriate treatments.

\section{Acknowledgements}

The authors' research is funded by a Marie Curie Individual Fellowship (International re-Integration Programme Proposal Nº 041304-ChAirDis) to Vivienne Duggan, which funds Carolyn Cummins. The authors would like to thank Mary Gallagher, Tommy McGeady and Eva Maischberger for their help.

\section{References}

Bain, F. T. (2004). Management of the foal from the mare with placentitis: A clinician's approach. In: Proceedings of the 50th Annual Convention of the American Association of Equine Practitioners. Denver, Colorado. Ithaca: International Veterinary Information Service (www.ivis.org) Document No. P1419.1204.

Bucca, S., Fogarty, U., Collins, A. and Small, V. (2005). Assessment of fetoplacental well-being in the mare from mid-gestation to term: Transrectal and transabdominal ultrasonographic features. Theriogenology 64: 542-557. Calderwood Mays, M. B., LeBlanc, M. M. and Paccamonti, D. (2002).

Route of fetal infection in a model of ascending placentitis. Theriogenology 58: 791-792.

Card, C.E. and Wood, M.R. (1995). Effects of acute administration of clenbuterol on uterine tone and equine fetal and maternal heart rates. Biol Reprod Monogr 1: 7-11.

Curran, S. and Ginther, O. J. (1995). M-mode ultrasonic assessment of equine fetal heart rate. Theriogenology 44: 609-617.

Daels, P. F., Besognet, B., Hansen, B., Mohammed, H., Odensvik, K. and Kindahl, H. (1996). Effect of progesterone on prostaglandin f2 alpha secretion and outcome of pregnancy during cloprostenol-induced abortion in mares. Am J Vet Res 57: 1331-1337.

Doherty, G.M., Jensen, J.C., Alexander, H.R., Buresh, C.M. and Norton, J.A. (1991). Pentoxifylline suppression of tumor necrosis factor gene transcription. Surgery 110 (2): 192-198. 
England, G. C. W. (1996). Allen's fertility and obstetrics in the horse. $2^{\text {nd }}$ Edition, pp 49-53 Cambridge: Blackwell Science Ltd.

Fowden, A. L., Ousey, J.C. and Forhead, A.J. (2004). Nutritive and endocrine functions of the equine placenta. In: Proceedings of a Workshop on the Equine Placenta. pp 36-48 Kentucky: University of Kentucky. Geor, R. J., Weiss, D. J., Burris, S. M. and Smith, C. M., (1992) Effects of furosemide and pentoxifylline on blood flow properties in horses. Am J Vet Res 53 (11): 2043-9

Giles, R. C., Donahue, J. M., Hong, C. B., Tuttle, P. A., Petrites-Murphy, M. B., Poonacha, K. B., Roberts, A. W., Tramontin, R. R., Smith, B. and Swerczek, T. W. (1993). Causes of abortion, stillbirth, and perinatal death in horses: 3,527 cases (1986-1991). J Am Vet Med Assoc 203: 1170-1175. Handler, J., Konigshofer, M., Kindahl, H., Schams, D. and Aurich, C. (2003). Secretion patterns of oxytocin and PGF2 alpha-metabolite in response to cervical dilatation in cyclic mares. Theriogenology 59: 1381-91. Hillier, S. L., Nugent, R. P., Eschenbach, D. A., Krohn, M. A., Gibbs, R. S., Martin, D. H., Cotch, M. F., Edelman, R., Pastorek, J. G., Rao, A. V., McNellis, D., Regan, J.A., Carey, J.C. and Klebanoff, M. A. (1995). Association between bacterial vaginosis and preterm delivery of a lowbirth-weight infant. The vaginal infections and prematurity study group. N Engl J Med 333: 1737-1742.

Howe, L., Wiggins, R., Soothill, P. W., Millar, M. R., Horner, P. J. and Corfield, A. P. (1999). Mucinase and sialidase activity of the vaginal microflora: Implications for the pathogenesis of preterm labour. Int J STD AIDS 10: 442-447.

Indecon International Economic Consultants (2004). An assessment of the economic contribution of the thoroughbred breeding and horse racing industry in Ireland. European Breeders Fund, Horse Racing Ireland and Irish Thoroughbred Breeders' Association. Indecon.

Katz, D. F., Slade, D. A. and Nakajima, S. T. (1997). Analysis of preovulatory changes in cervical mucus hydration and sperm penetrability. Adv Contracept 13: 143-151.

Kelleman, A. A., Luznar, S. L., Lester, G. D., Paccamonti, D. L. and LeBlanc, M. M. (2002). Evaluation of transrectal ultrasonographic combined thickness of the uterus and placenta (ctup) in a model of induced ascending placentitis in late gestation in the pony mare. Theriogenology 58: 845-848.

Lagow, E., DeSouza, M. M. and Carson, D. D. (1999). Mammalian reproductive tract mucins. Hum Reprod Update 5: 280-292. LeBlanc, M. M. (2004a). Ascending placentitits in the mare: Does treatment really help? In: Proceedings of the 10 Congresso Nazionala Multisala SIVE. Perugia. Ithaca: International Veterinary Information Service (www.ivis.org)

LeBlanc, M. M. (2004b). Ascending placentitis in the mare: What we learned from an experimental model. In: Proceedings of the 10 Congresso Nazionala Multisala SIVE. Perugia. Ithaca: International Veterinary Information Service (www.ivis.org)

LeBlanc, M. M. (2004c). Infertility: Mares that conceive and lose their pregnancy. In: Proceedings of the 10 Congresso Nazionala Multisala SIVE. Perugia. Ithaca: International Veterinary Information Service (www.ivis. org).

LeBlanc, M. M., Giguere, S., Brauer, K., Paccamonti, D.L., Horohov, D. W., Lester, G. D., O'Donnell, L.J., Sheerin, B.R., Pablo, L. and Rodgerson, D. H. (2002). Premature delivery in ascending placentitis is associated with increased expression of placental cytokines and allantoic fluid prostaglandins e2 and $\mathrm{f} 2$. Theriogenology 58: 841-844. LeBlanc, M. M., Macpherson, M. and Sheerin, P. (2004). Ascending placentitis: What we know about pathophysiology, diagnosis, and treatment. In: Proceedings of the 50th Annual Convention of the American Association of Equine Practitioners. Denver, Colorado. Ithaca: International Veterinary Information Service (www.ivis.org).

Leprat, R. and Michel-Briand, Y. (1980). Extracellular neuraminidase production by a strain of Pseudomonas aeruginosa isolated from cystic fibrosis. Ann Microbiol (Paris) 131B: 209-222.

Macpherson, M. L. (2005). Treatment strategies for mares with placentitis. Theriogenology 64: 528-534.

McGeady, T. A., Quinn, P. J., Fitzpatrick E. S. and Ryan, M. T. (2006)

Veterinary Embryology. Cornwall: Blackwell Publishing.

McGlothlin, J. A., Lester, G. D., Hansen, P. J., Thomas, M., Pablo,

L., Hawkins, D. L. and LeBlanc, M. M. (2004). Alteration in uterine contractility in mares with experimentally induced placentitis. Reproduction 127: 57-66.

McKinnon, A. O. and Voss, J.M. (1993a). Equine reproduction. Philadelphia: Lea \& Febiger.

McKinnon, A. O. and Voss, J.M. (1993b). Equine reproduction Philadelphia: Lea \& Febiger.

Morresey, P. R. (2004). How to perform a field assessment of the equine placenta. In: Proceedings of the 50th Annual Convention of the American Association of Equine Practitioners. Denver, CO, USA. Ithaca: International Veterinary Information Service (www.ivis.org) Document no. P1474.1204. Morresey, P. R. (2005). Prenatal and perinatal indicators of neonatal viability. Clinical Techniques in Equine Practice 4: 238-249.

Morris, S., Kelleman, A. A., Stawicki, R. J., Hansen, P. J., Sheerin, P. C., Sheerin, B. R., Paccamonti, D. L. and Leblanc, M. M. (2006). Transrectal ultrasonography and plasma progestin profiles identifies fetoplacental compromise in mares with experimentally induced placentitis. Theriogenology 67: 681-691.

Murchie, T. A., Macpherson, M., LeBlanc, M.M., Luznar, S. and Vickroy, T.W. (2003). A microdialysis model to detect drugs in the allantoic fluid of pregnant pony mares. In: Proceedings of the 49th Annual Convention of the American Association of Equine Practitioners. New Orleans, Louisiana. Ithaca: International Veterinary Information Service (www.ivis.org) Nishikawa, Y. (1959). Studies on reproduction in horses. Tokyo: Japan Racing Association.

Ousey, J. C. (2004). Peripartal endocrinology in the mare and foetus. Reprod Domest Anim 39: 222-231.

Ousey, J. C., Rossdale, P. D., Palmer, L. and Fowden, A. L. (1999). The role of the adrenals and effects of ACTH treatment on development and maturation of the equine fetus in late gestation. In: Havemeyer Foundation Monograph Series 2 : Proceedings of a workshop on fetomaternal control of pregnancy. Barbados, West Indies. Havemeyer Foundation

Ousey, J. C., Houghton, E., Grainger, L., Rossdale, P. D. and Fowden, A. L. (2005). Progestagen profiles during the last trimester of gestation in thoroughbred mares with normal or compromised pregnancies. Theriogenology 63: 1844-1856.

Palmer, E., Chauvatte-Palmer, P., Duchamp, G. and Levy, I. (2002). Lack of effect of clenbuterol for delaying parturition in late pregnant mares. Theriogenology 58: 797-799.

Reef, V. B., Vaala, W. E., Worth, L. T., Spencer, P. A. and Hammett, B. (1995). Ultrasonographic evaluation of the fetus and intrauterine environment in healthy mares during late gestation. Veterinary Radiology $\mathcal{E}$ Ultrasound 36: 533-541.

Reimer, J. M. (1997). Use of transcutaneous ultrasonography in complicated latter-middle to late gestation pregnancies in the mare: 122 cases. In: Proceedings of the 43rd American Association of Equine Practitioners Annual Convention. Phoenix, Arizona. Ithaca: International Veterinary 
Information Service (www.ivis.org).

Renaudin, C. D., Troedsson, M. H., Gillis, C. L., King, V. L. and

Bodena, A. (1997). Ultrasonographic evaluation of the equine placenta by transrectal and transabdominal approach in the normal pregnant mare. Theriogenology 47: 559-573.

Renaudin, C. D., Liu, I. K., Troedsson, M. H. and Schrenzel M.D. (1999). Transrectal ultrasonographic diagnosis of ascending placentitis in the mare: a report of two cases. Equine Vet Educ. 11: 69-74.

Ricketts, S. W. (2007). The Veterinary Surgeon in Modern Studfarm Practice. In: Equine stud medicine course. Newmarket: Lifelearn Limited Rossdale, P. D., Ousey, J. C., Cottrill, C. M., Chavatte, P., Allen, W. R. and McGladdery, A. J. (1991). Effects of placental pathology on maternal plasma progestagen and mammary secretion calcium concentrations and on neonatal adrenocortical function in the horse. J Reprod Fertil Suppl 44: 579-590.

Ryan, P., Vaala, W. and Bagnell, C. (1998). Evidence that equine relaxin is a good indicator of placental insufficiency in the mare. In: Proceedings of the 44th Annual Convention of the American Association of Equine Practitioners. Baltimore, Maryland. Ithaca: International Veterinary Information Service (www.ivis.org).

Santschi, E. M. and Papich, M. G. (2000). Pharmacokinetics of gentamicin in mares in late pregnancy and early lactation. J Vet Pharmacol Ther 23: 359-363.

Schlafer, D. H. (2004). Postmortem examination of the equine placenta, foetus and neonate: Methods and interpretation of findings. In: Proceedings of the 50th Annual Convention of the American Association of Equine Practitioners. Denver, CO, USA. Document no. P1418.1204. Ithaca: International Veterinary Information Service (www.ivis.org) Small, Victoria (2000). Transabdominal and transrectal ultrasound scanning of the pregnant mare from five months to term. Masters in veterinary medicine thesis University College Dublin, Dublin, Ireland.

Smith, K. C., Blunden, A. S., Whitwell, K. E., Dunn, K. A. and Wales, A. D. (2003). A survey of equine abortion, stillbirth and neonatal death in the uk from 1988 to 1997. Equine Vet J 35: 496-501.

Soong, G., Muir A., Gomez, M. I., Waks, J., Reddy, B., Planet, P., Singh, P. K., Kaneko, Y., Wolfgang, M. C., Hsiao, Y. S., Tong, L. and Prince, A. (2006). Bacterial neuraminidase facilitates mucosal infection by participating in biofilm production. J. Clin. Invest. 116: 2297-2305. Staudinger, T., Presterl, E., Graninger, W., Locker, G.J., Knapp, S., Laczika, K., Klappacher, G., Stoiser, B., Wagner, A., Tesinsky, P., Kordova, H. and Frass, M. (1996). Influence of pentoxifylline on cytokine levels and inflammatory parameters in septic shock. Intensive Care Med. 22: 888-893.

Stawicki, R. J., Ruebel, H., Hansen, P. J., Sheerin, B. R., O'Donnell, L. J., Lester, G. D., Paccamonti, D. L. and LeBlanc, M. M. (2002). Endocrinological findings in an experimental model of ascending placentitis in the mare. Theriogenology 58: 849-852.

Stewart, D. R., Stabenfeldt, G. H. and Hughes, J. P. (1982). Relaxin activity in foaling mares. J Reprod Fertil Suppl 32: 603-609.

Terblanche, H. M. and Maree, L. (1981). Plasma progesterone levels in the mare during the oestrous cycle and pregnancy. J S Afr Vet Assoc 52: 181-185.

Troedsson, M. H. and Macpherson, M.L. (2006). Diagnosis and treatment of equine placentitis. In: Proceedings of the XXVIII Congreso Anual. Mexico. (www.ammvee.org.mx).

Troedsson, M. H. and Sage, A.M. (2001). Fetal/placental evaluation in the mare. In: Recent Advances in Equine Reproduction. Edited by B.A. Ball. Ithaca: International Veterinary Information Service (www.ivis.org)
Document No. A0203.0501.

Troedsson, M. H. and Zent, W.W. (1997). Transrectal ultrasonography of the placenta in normal mares and mares with pending abortion: A field study. In: Proceedings of the 43rd American Association of Equine Practitioners Annual Convention. Phoenix, Arizona. Ithaca: International Veterinary Information Service (www.ivis.org).

Vaala, W. E. (1999). Peripartum asphyxia syndrome in foals. In: Proceedings of the $45^{\text {th }}$ American Association of Equine Practitioners Annual Convention. Albuquerque, New Mexico. Ithaca: International Veterinary Information Service (www.ivis.org). 